\title{
Extensive Green Roof Ecological Benefits in Latvia
}

\author{
Rihards Rušenieks ${ }^{1}$, Agris Kamenders ${ }^{2},{ }^{1-2}$ Riga Technical University
}

\begin{abstract}
Extensive green roof ecological benefits are studied in this paper. The research contains a brief explanation about green roof technology and green roof ecological benefits. Green roof capability to retain rainwater runoff by accumulating it in storage layers and conducting it back into the atmosphere through evapotranspiration is studied and modeled. Modeling is done in Stormwater Management Model 5.0 software. The model is based on an existing warehouse-type building located in Riga and hourly Riga climatic data of 2012. Evaluation of the model is carried out and future study fields of green roof ecological benefits are discussed.
\end{abstract}

Keywords - green roof, extensive green roof, rainwater retention, green urban building, urban planning, energy efficiency.

\section{INTRODUCTION}

Green roof technology is becoming more and more widespread in the world. Apart from esthetical value, green roofs have many ecological benefits as well. Green roofs are basically vegetation layers which are put on the roof of a building (either on new buildings or refurbishing existing ones) with supportive layers. Two types of green roofs exist extensive and intensive systems. An extensive green roof is lightweight $\left(60-150 \mathrm{~kg} / \mathrm{m}^{2}\right)$, non-habitable by people. The vegetation consists of grass, moss, succulents, stonecrops, irrigation and maintenance is not required. Intensive green roof systems are roof gardens, which are heavyweight (180 $500 \mathrm{~kg} / \mathrm{m}^{2}$ ), fulfill a recreational function with the possibility of urban gardening. The vegetation may be shrubs and trees, and irrigation and regular maintenance is required. Intensive green roofs are more suitable for areas with high population density, but in case of Latvia (and other Baltic countries) extensive systems are more appropriate.

Extensive green roof consists of several layers. These layers are (from bottom to top):

- Waterproof layer. Forms the base of the green roof, protects the structure from impact of water;

- Insulation layer. This layer is optional on any roof, it prevents heat loss in the winter and cool air conduction in the summer;

- Drainage layer. Provides preferable conditions for plant growth by ensuring aridity in soil and preventing anaerobe environment. This layer also drains excess water from the soil to the roof's drainpipes after heavy rainfall;

- Filtration layer. This layer prevents soil particles from washing into the drainage layer, causing drainage blocking and reducing flow;

- Soil layer. Soil is necessary for maintaining vegetation. Natural soil is too heavy to be placed on roofs. Soil must be lightweight and also must preserve a certain amount of water, allowing excessive water to dry, and the soil must contain plant nutrients, at the same time preventing them from washing out to sewage;

- Plants. In selection of plants An important aspect in the selection of plants is the esthetic requirements. Different plants change color throughout the year. However the main criteria are plant vitality and resistance to unfavorable conditions. Frequent choice is Sedum, Delosperma, Euphorbia un Sempervivum.[1]

\section{ECOLOGICAL BENEFITS IN CASE OF LATVIA}

Green roofs have many ecological benefits. In case of Latvia, these benefits could be pointed out as the most important:

- increase of building energy efficiency (insulation and passive cooling). Green roofs act as an additional insulation layer, but passive cooling occurs by conduction of heat through the roof via evapotranspiration of gained rainwater [2];

- habitat creation for plants and animals. When buildings are constructed, green zone is permanently destroyed. Green roofs are the way we can compensate the loss of green zone in the city by putting it back on the top of the building;

- air pollution removal. Green roofs act as usual grass and clear air from particular matter by retaining it in the vegetation layer [3];

- decrease of urban heat effect. All cities more or less suffer from increased average annual temperature compared to their surroundings. This is mainly because of the albedo effect of construction materials which are used in the construction of buildings and streets. Other factors are industrial and technological processes emitting heat, reduction of wind speed etc. It is already proven that green roofs decrease urban heat effect because of better albedo and evapotranspiration [4];

- cityscape improvements. Green roofs can be used in urban planning as a way to green the cities and make the sight more esthetically attractive and relaxing to citizens [5];

- stormwater runoff retention. Green roofs can accumulate certain amounts of rainwater, thus (during heavy rainfalls) preventing it from surcharging the city's sewage system and flooding streets nearby $[6,7,8]$.

Additional benefits which have not yet been studied might include electromagnetic radiation screening and roof fireproof increase.

In some countries there could also be financial benefits in the form of property and/or rainwater runoff tax and fee reductions. In any case, the effect that the presence of a green 
roof might have on increasing the building's market value could also be viewed as a financial benefit.

Even though green roof layers are made out of synthetic materials, one of the benefits is protection of the roof deck and increase of its life, in this way saving resources required for roof repairs.

In the author's previous studies, the impact of extensive green roofs on a building`s energy demand was studied. A one-storey private house was modeled in CAD software "Desing Builder" (Design Builder is graphical interface of EnergyPlus - an energy simulation program developed by USA Department of Energy). Energy Plus is one of the most advanced and widely used building energy simulation programs [9]. For the purposes of modeling, a real house project was chosen with a $285 \mathrm{~m}^{2}$ area and a 15 degree sloped roof. Data about the building envelope materials, green roof parameters, geographical location (Riga), HVAC system and activity of inhabitants in different zones were included in the model. Energy simulation demand was carried out for a one year period, based on hourly climatic data of Kaunas, Lithuania (closest data available).

Results showed a slight decrease $(\sim 3 \%)$ in total building energy demand. Only this factor alone does not justify green roof implementation, so other ecological and financial benefits must be evaluated. One of them is rainwater runoff reduction from the roof.

\section{GREEN ROOF CAPACITY FOR OF RAINWATER RETENTION}

Green roof as an option for water retention was first mentioned in in 1985.[10] Since then, many additional studies have been carried out. Review of modern literature sources and reanalyze of data to derive empirical model has been done by Mentens, Raes and Hermy.[11] In this research, data was collected from literature review (18 publications and 628 records). Data about roof properties and precipitation and runoff was collected.

The literature review results clearly showed that the runoff is mainly determined by the roof type. The annual precipitation, type of roof, number of layers and depth of the substrate layers are significantly correlated with the yearly runoff $(p<0.05)$, while the age of the green roof, slope angle and length are not significantly correlated with the yearly runoff $(p>0.05)$. For non-greened roofs, runoff is solely determined by precipitation. Annual runoff for various roof types as a percentage of the total annual rainfall can be seen in Figure 1. Analysis on the seasonal level was carried out as well and obviously it was concluded, that the retention is significantly lower in winter than in summer.[11]

German Green roof FLL Guidelines (Forschungsgesellschaft Landschaftsentwicklung Landschaftsbau) provides following Fig. 1 and Table I.

\section{IMPORTANCE OF RAINWATER RUNOFF REDUCTION IN LATVIA}

Vast and devastating flood risk is unlikely in Latvia due to country`s advantageous geographic location. However each year wide territories in Latvia face floods caused by meltwaters or stormwaters.

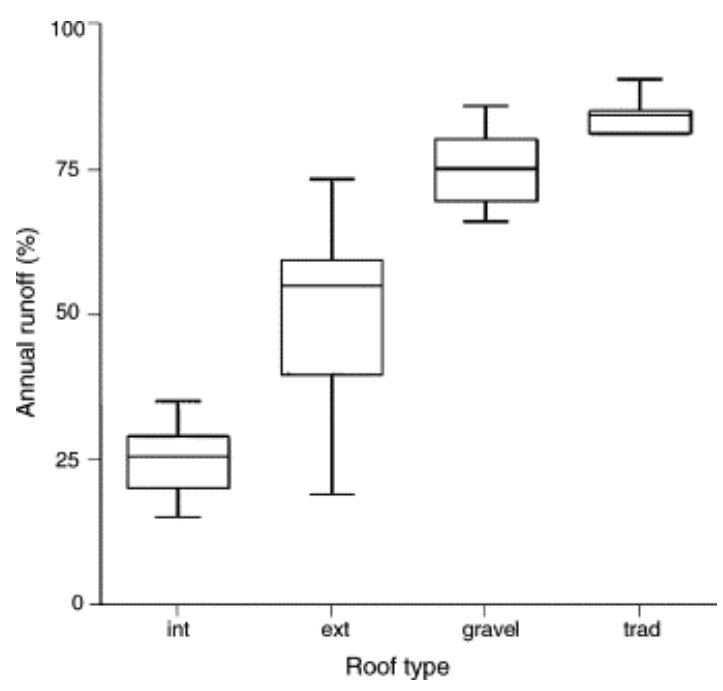

Fig.1. Annual runoff for various roof types as a percentage of the total annual rainfall [9]

TABLE I

RAINWATER RUNOFF REDUCTION ACCORDING TO FLL GUIDELINES [17]

\begin{tabular}{|c|l|c|}
\hline $\begin{array}{c}\text { Thickness of green } \\
\text { roof [mm] }\end{array}$ & \multicolumn{1}{|c|}{ Vegetation } & $\begin{array}{c}\text { Water retention, } \\
\text { annual [\%] }\end{array}$ \\
\hline $20-40$ & Moss/stonecrops & 40 \\
\hline $40-60$ & Stonecrops/moss & 45 \\
\hline $60-100$ & Stonecrops/moss/herbs & 50 \\
\hline $100-150$ & Stonecrops/herbs/grass & 55 \\
\hline $150-200$ & Grass/herbs & 60 \\
\hline
\end{tabular}

In the National program of flood risk evaluation and management 2008-2015 (Plūdu riska novērtēšanas un pārvaldības nacionālajā programma 2008.-2015.gadam) it is admitted, that in Riga the most serious flood risk could caused by strong north-west winds (storms). Under these circumstances, the water level rises in the lower part of the river Daugava and in the lakes Baltezers and Ķî̌ezers, causing flooding in coastal regions and risks to coastal erosion.

Flood threats in Riga evolve from intense and long-lasting precipitation, which can cause water levels to rise in the rivers Daugava and Lielupe and in lake Ķī̌sezers, thus leading to flooding low-lying areas, basements of buildings and negatively affecting the sewage system, which transports wastewaters to the biological purification plant "Daugavgrīva".[12]

In the Riga development plan 2006-2018 environmental impact assessment (Rīgas attīstības plāna 2006.-2018. gadam ietekmes uz vidi stratēéiskā novērtējuma pārskats) in section 4.5 "Waste waters and purification" the following is mentioned:

"Authors of this summary consider - if in the future the water supply and sewage projects will not be financed, the quality of surface and ground water will be affected significantly. If the construction of a water supply and sewage grid will not happen, development possibilities of new 
territories will reduce. Unfortunately, the Riga development plan does not fully solve rainwater catchment system improvement, which is one of the most important environmental problems in the city."'[13]

And in section 7.8 "Water supply and sewage system development solution" it states:

"Authors of this summary consider, that planned central sewage system and water supply grid of new perspective districts is not economically justified.

Since the plan does not solve issues about rainwater catchment system improvement possibilities, in the future problems in wastewater treatment plant operations will remain, including wastewater sludge usage in agricultural land fertilization.

In the future problems will be caused by the city`s rainwater catchment and treatment. "[13]

One of the green roof functions is rainwater runoff retention, accumulating it in soil and storage layer, from where it later transfers back in the atmosphere, evaporating from plants and soil by evapotranspiration. In that way, a certain amount of rainwater does not reach the sewage and prevents it from surcharge and decreases load of sewage system. In studies performed by USA Connecticut university, it is found that green roof accumulates $51,4 \%$ of precipitation $\left(248 \mathrm{~m}^{2} \mathrm{big}\right.$ green roof was observed in experiment).[14] Unfortunately nothing can be found about green roofs in neither "Riga long term development strategy till 2025" nor in the project "Flood risk management plan of Riga city".

However green roofs as one of the possibilities to catch and accumulate rainwater in Riga city is mentioned in conclusions of Latvia University of Agriculture $\mathrm{PhD}$ student's Reinis Ziemelnieks doctorate thesis "Rainwater influence on common sewage system operation" (property tax reduction for buildings with green roof is also mentioned).[15] However this possibility is not studied in more depth.

Therefore green roof rainwater runoff reduction modeling must be carried out.

\section{MODEL AND PARAMETERS DESCRIPTION}

The USA Environmental Protection Agency (EPA) software Storm Water Management Model 5 (SWMM), which is widely used by other authors, is chosen for modeling. The software is based on a system first developed in 1971, currently its fifth version is used. The latest updates were made by USA EPA Nation risk management research laboratory`s Water supply and water resource section in cooperation with private sector. SWMM performs dynamic perception and precipitation runoff simulation both for single and long term events. Rainwater runoff quality and quantity is calculated. Software is used mostly for urban environment simulation. Waste water simulation is performed with water catchments, modeling precipitation on them as well as runoff. Sewage system is modeled as well, including pumps, treatment plants and storages.

In the fifth version of SMWW it is possible to model green roofs by LID (Low Impact Development) controllers. LID controller is created to catch the surface runoff and create combination of runoff water accumulation, infiltration and evaporation. They are added as runoff surfaces properties. SWMM has 5 types of LIDs:

- bio-retention cells;

- infiltration trenches;

- porous pavement;

- rain barrels;

- vegetative swales.

The most correct green roof modeling can be done by bioretention cells. Bio-retention cells are depressions that contain plants in artificially created soil. This system is placed upon the drainage layer and provides accumulation, infiltration and transpiration of precipitation and runoff waters of surrounding. Rainwater gardens, street greeneries and green roofs are modeled with this method.

LID controllers are created as a combination of vertical layers, the properties of which are determined as units on area. During the simulation SWMM calculates moisture balance, keeping track of amount of water, conducting through layers and amount of stored water. Bio-retention cell modeling is performed as in this scheme:

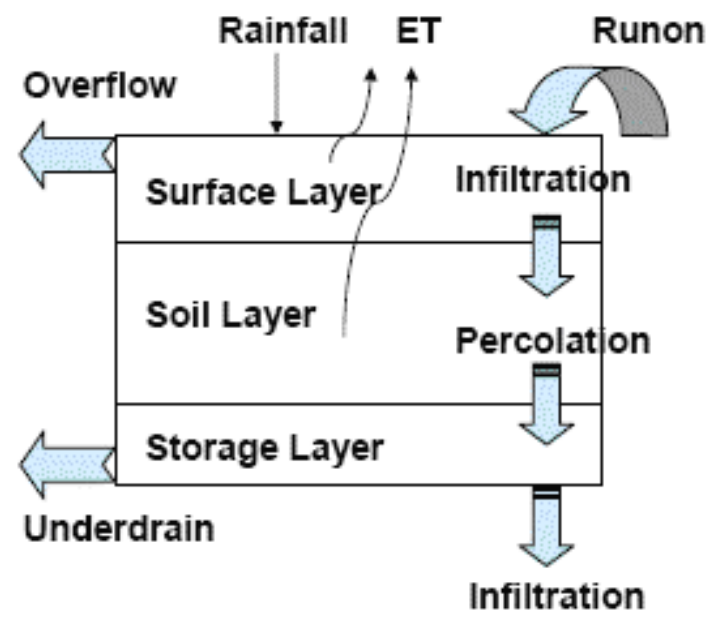

Fig.2. Bio-retention cell model scheme [16]

Surface layer - corresponds to the ground surface that receives direct rainfall, stores excess inflow in depression storage and generates surface outflow that either enters the drainage system or flows onto downstream land areas.

Soil layer - is the engineered soil mixture used in bioretention cells to support vegetative growth.

Storage layer - provides storage in bio-retention cells (in case of green roof usually a felt carpet).

Underdrain - conveys water out of the storage layer of bioretention cell into common outlet pipe.

Transpiration of precipitation happens in the system as well.

Modeling is done on a comparative basis implemented by a LID controller, simulating rainfall runoff on an equal area of the buildings, in one case -with an ordinary roof, in other the case with a green roof. A warehouse-type, flat roof building with a total space of $2425 \mathrm{~m}^{2}$ is chosen. Building serves for entertainment purposes and is located in Riga. 


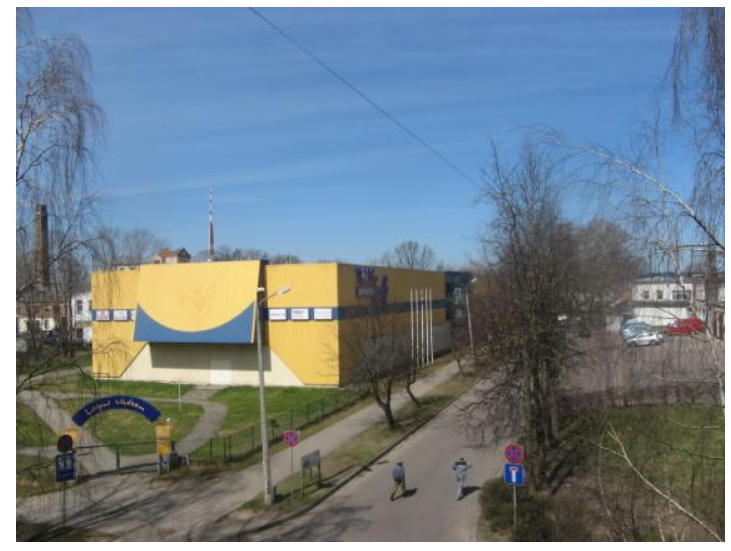

Fig. 3. Building of the model

During heavy rainfalls, the sewage system is surcharged and surrounding streets are heavily flooded.

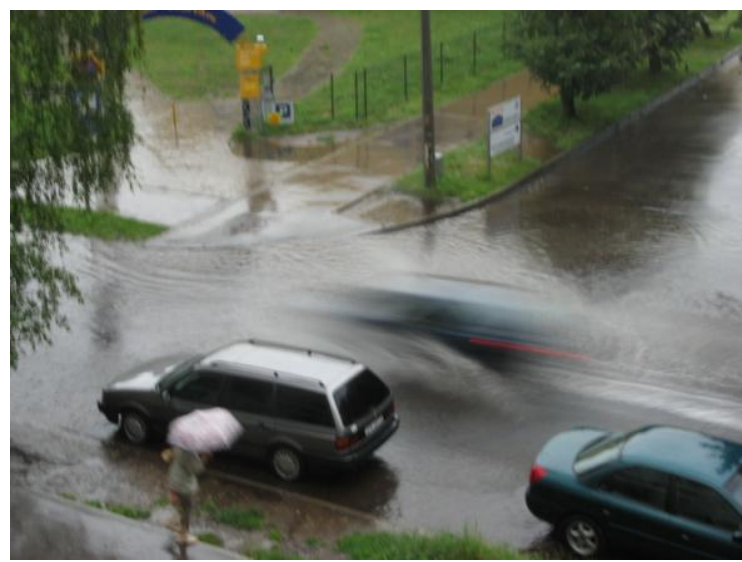

Fig.4. Problem of flooded streets during heavy rainfalls

Modeled building dimensions are as follows:

Width of the building - $25 \mathrm{~m}$

Length of the building - $97 \mathrm{~m}$

Roof space - $2425 \mathrm{~m}^{2}=0,6$ acres (SWMM uses acres as area unit).

In one case roof is ordinary (Parastais_jumts), in other case roof is extensive green roof (Zalais_jumts).

Both buildings are joined to the city`s sewage system (J1 and J2 - independently). The rainfall source is added (Nokrisni).

LID controller parameters are set as follows:

LID Type: Bio-retention cell

Process layers - Surface. Describes surface of green roof.

Storage Depth - maximum depth to which water can pond above the surface of the unit before overflows occur. Since green roofs can be with border and without, this parameter is set to $0 \mathrm{~mm}$.

Vegetative volume fraction - the volume of the storage area above the surface that is filled with vegetation. In case of extensive green roof assumed as $80 \%$.
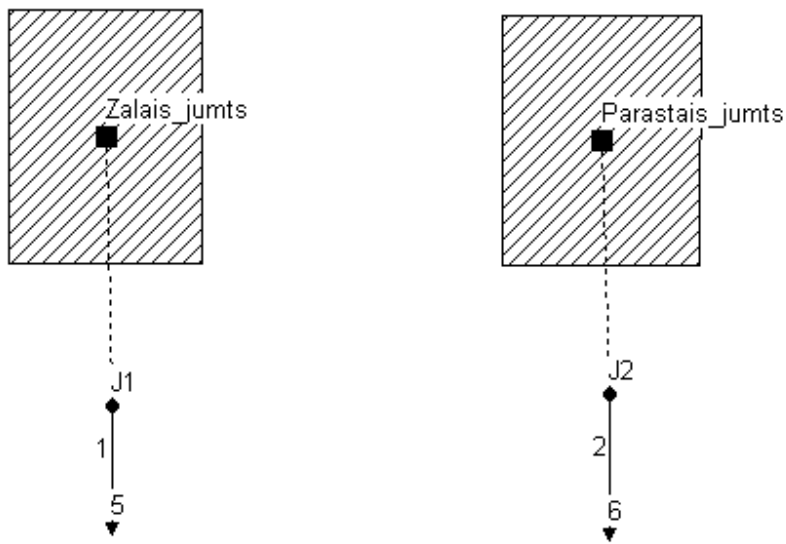

Fig.5. Model in SWMM

Surface roughness - applies to porous pavements and vegetative swales, is left as 0 .

Surface slope - applies to porous pavements and vegetative swales, is left as 0 .

Process layers - Soil. Describes properties of substratum, placed in roof.

Thickness - thickness of substratum. Ass. as $100 \mathrm{~mm}$, which is typical to extensive green roof.

Porosity - porosity of substratum. Assumed as 0,5.

Field capacity - volume of pore water relative to total volume after the soil has been allowed to drain fully. Assumed as 0,2 .

Wilting point - volume of pore water relative to total volume for a well dried soil where only bound water remains. Assumed as 0,1.

Conductivity - hydraulic conductivity for the fully saturated soil. Assumed as $0,5 \mathrm{~mm} / \mathrm{h}$.

Conductivity slope - slope of the curve of $\log$ (conductivity) versus soil moister content (dimensionless). Assumed as 10 .

Suction head - the average value of soil capillary suction along the wetting front. Ass. as 3,5 mm.

Process layers - Storage. Describes rainwater storage and drainage layer properties.

Height - height of layer. Drainage and storage layer height for flat green roof usually is $30 \mathrm{~mm}$ (sum of both).

Void ratio - the volume of void space relative to the volume of solids in the layer. Assumed as 0,75.

Conductivity - conductivity of layer. Assumed as $10 \mathrm{~mm} / \mathrm{h}$.

Clogging factor - clogging speed of layer. Assumed as 0 .

Configuration of LID controller usage is necessary to determine, how the LID controller will interact with given rainwater subcatchment.

In this case it is configured as one unit, which occupies all area of subcatchment (in controller area covered by vegetation is already set, so there is no need to set it again).

Initial water saturation is set as 0 . 


\section{Simulation}

For simulation the following parameters are set:

- water infiltration model: Green Ampt'

- water runoff routing: Kinematic Wave;

- period of simulation (1. January 2012 - 31. December 2012);

- time step (3600 seconds or 1 hour);

- hourly precipitation amount of simulation period in $\mathrm{mm}$;

- daily minimal and maximal air temperature for simulation period;

- average monthly wind speed;

- snow melting parameters.

The simulation was carried out for a one year period (365 days). Meteorological data necessary for simulation were obtained from the Latvian Environment, Geology and Meteorology Centre observation records archive. The observation station chosen is "Rīga - Universitāte" (University of Latvia main building at Raiņa bulvāris 19).

Simulation period is set as one year (2012).

Simulation time step is set as one hour due to precipitation data, which is available as hourly.

Precipitation data is obtained from the Latvian Environment, Geology and Meteorology Centre archive and converted to SWMM supported format. Data is entered in Notepad file, which is converted to .dat file. Data format is:

month/day/year hours: minutes: precipitation $(\mathrm{mm})$

Example of format is as follows (only days and hours with precipitation is entered):

$\begin{array}{rrr}01 / 02 / 2012 & 00: 00 & 0.0 \\ 07: 00 & 0.1 \\ 11: 00 & 0.2 \\ 12: 00 & 1.2 \\ 13: 00 & 1.0 \\ 14: 00 & 1.2 \\ 15: 00 & 1.4 \\ 17: 00 & 0.1 \\ 18: 00 & 0.1 \\ 01 / 04 / 2012 & 00: 00 & 0.0 \\ 02: 00 & 0.2 \\ 03: 00 & 0.2 \\ 04: 00 & 0.2\end{array}$

New TimeSeries is created in software out of entered data, which is assigned to precipitation source Rain Gage "Nokrisni".

The temperature data file is created manually. SWMM requires entering only minimal and maximal temperature of day. These data are acquired, extracting average temperatures from the Latvian Environment, Geology and Meteorology Centre hourly temperature archive. Data is entered in Notepad file, which is converted to .dat file. Data format is as follows:

Name of station Year Month Day Minimal temp. Maximal temp.
Temperatures are entered in Fahrenheit scale (SWMM was created in USA).

Example of format is this:

RIGA $20121 \quad 1 \quad 28.44 \quad 33.26$

RIGA $20121231.46 \quad 37.58$

RIGA $20121 \quad 3 \quad 34.52 \quad 39.92$

RIGA $20121 \quad 4 \quad 35.24 \quad 42.08$

RIGA $20121 \quad 5 \quad 32.72 \quad 39.92$

Temperature data is entered in software climatic configurations "Climatology/Temperature". Evaporated water amount is automatically calculated from these values.

Average monthly wind speeds in Riga are entered in the climatic conditions. Wind speed is entered in miles per hour. These wind speed values are used (Latvian Environment, Geology and Meteorology Centre data for 2012):

TABLE II

AVERAGE WIND SPEED IN Riga (2012)

\begin{tabular}{|l|l|l|}
\hline & $\mathrm{km} / \mathrm{h}$ & $\mathrm{m} / \mathrm{h}$ \\
\hline January & 3.38 & 2.11 \\
\hline February & 3.10 & 1.94 \\
\hline March & 3.60 & 2.25 \\
\hline April & 3.20 & 2.00 \\
\hline May & 2.96 & 1.85 \\
\hline June & 2.90 & 1.81 \\
\hline July & 2.85 & 1.78 \\
\hline August & 2.67 & 1.67 \\
\hline September & 3.23 & 2.02 \\
\hline October & 2.92 & 1.83 \\
\hline November & 3.29 & 2.06 \\
\hline December & 3.65 & 2.28 \\
\hline
\end{tabular}

If the simulation is successful, the software shows size of continuity error. This error serves as a validation tool for the model and shows a percentage difference from initial water amount + total inflow in sewage system and final water amount + total outflow from sewage. If the error exceeds $10 \%$, feasibility of the model has to be questioned.[16] In this case the surface runoff error was $-0,42 \%$ and flow routing error was $-0,07 \%$. This proves that the model is very accurate.

\section{RESULTS AND DISCUSSION}

Results about rainwater runoff from the warehouse-type building in Riga with a total space $2425 \mathrm{~m}^{2}$ for the year 2012 are shown in the Table III.

Explanation of results:

Subcatchment - surface of precipitation catchment. In case of this model it was previously described $2425 \mathrm{~m}^{2}$ warehouse type building with flat roof - in one scenario with green roof, on other scenario with ordinary roof;

Total runon - discharge from other water sources (apart from precipitation);

Total evap - amount of evaporated water (excluding transpiration from plants); 
Total infil - infiltration in roof (in case of green roof in soil and storage layer);

Total runoff - rain water runoff from roof to city`s sewage;

Runoff coeff - proportion of runoff water and accumulated water for given surface.

TABLE III

RESUlTS OF SWMM MODEL

\begin{tabular}{|l|c|c|}
\hline Subcatchment & $\begin{array}{l}\text { Zalais_jumts (Green } \\
\text { roof) }\end{array}$ & $\begin{array}{l}\text { Parastais_jumts } \\
\text { (Ordinary roof) }\end{array}$ \\
\hline Total precip & 717,50 & 717,50 \\
\hline Total runon & 0,00 & 0,00 \\
\hline Total evap & 25,57 & 7,11 \\
\hline Total infil & 356,52 & 0,00 \\
\hline Total runoff & 319,55 & 715,96 \\
\hline Runoff coeff & 0,445 & 0,998 \\
\hline
\end{tabular}

Interpretation of results indicate that the total precipitation amount in 2012 was $717,5 \mathrm{~mm}$ (average is $700 \mathrm{~mm}$ ). The green roof has vegetation, soil and water storage layers, and, for that reason, runoff from the green roof was only 319,55 $\mathrm{mm}(45 \%)$. More than half $-356,52 \mathrm{~mm}(55 \%)$ - infiltrated in the soil and was absorbed by plants. This water was transported back in the atmosphere by transpiration. This process significantly could help sewage system to deal with runoffs. Small amounts of water $(25.57 \mathrm{~mm})$ evaporated immediately. In case of the ordinary roof almost all rainwater was discharged in the city`s sewage system.

Further studies about green roof rainwater retention capabilities should be conducted with smaller time intervals (e.g. 1 minute) to more accurately determine rainwater runoff amount and sewage surcharge.

The number of buildings suitable for refurbishment with green roofs must be evaluated by analyzing serial residential building roof load carrying capacity.

Moreover, green roofs have many other ecological benefits not reviewed in this paper. The most important field of studies about green roof development should be about green roof possibilities to reduce air pollution and urban heat effect in Riga, as well as opportunities to create habitat for plants and animals in the city center.

\section{REFERENCES}

1. Layers of green roofs //http://www.wbdg.org/resources/greenroofs.php [15.02.2013]

2. H.F. Castletona,*, V. Stovinb, S.B.M. Beckc, J.B. Davisonb. Green roofs; building energy savings and the potential for retrofit, Energy and $\begin{array}{lllll}\text { Buildings } & 42 & (2010) & \text { pp } & 1582-1591\end{array}$ http://dx.doi.org/10.1016/j.enbuild.2010.05.004

3. J. Yang, Q. Yu, P. Gong. Quantifying air pollution removal by green roofs in Chicago, Atmospheric Environment 42 (31) (2008) pp 7266 7273. http://dx.doi.org/10.1016/j.atmosenv.2008.07.003

4. D. Banting et al., Report on the environmental benefits and costs of green roof technology for the City of Toronto, 2005.

5. M. Koehler, Plant survival research and biodiversity: lessons from Europe. Greening Rooftops for Sustainable Communities, Chicago, 2003, pp 313-322.

6. J. Mentens, D. Raes, M. Hermy. Green roofs as a tool for solving the rainwater runoff problem in the urbanized 21st century? Landscape and Urban Planning 77 (2006), pp 217-226. http://dx.doi.org/10.1016/j.landurbplan.2005.02.010

7. V. Stovin, N. Dunnett, A. Hallam. Green Roofs-getting sustainable drainage off the ground. 6th International Conference of Sustainable Techniques and Strategies in Urban Water Mangement (Novatech 2007), Lyon, France, 2007, pp. 11-18.
8. J.C. Berndtsson, L. Bengtsson, K. Jinno. Runoff water quality fromintensive and extensive vegetated roofs, Ecological Engineering 35 (3) (2009) pp 369-380. http://dx.doi.org/10.1016/j.ecoleng.2008.09.020

9. Sailor, D.J. A green roof model for building energy simulation programs. Energy and Buildings, 40 (8/2008), pp. 1466-1478.12.

10. Ernst W., Weigerding I. Oberflächenentwässerung, Gewässerentlastung durch ökologische/ökonomische Planung, Bundesblatt, 34 (11) (1985), pp 722-732.

11. Mentens J., Raes D., Hermy M. Green roofs as a tool for solving the rainwater runoff problem in the urbanized 21st century?Landscape and Urban Planning, Volume 77, Issue 3, (August 2006), pp 217-226. http://dx.doi.org/10.1016/j.landurbplan.2005.02.010

12. Plū du riska novērtēsanas un pārvaldības nacionālā programma 2008. 2015.gadam. Ministru kabineta 2007.gada 20.decembra rīkojums Nr.830. Rìga, 2007

13. Ietekmes uz vidi stratēgiskā novērtējuma Vides pārskata projekta kopsavilkums Rīgas attīistības plānam 2006.-2018. gadam. Rīgas Vides centrs „Agenda21”. Rīga, 2005

14. Bruce G., Clausen J. C. Effect of a modular extensive green roof on stormwater runoff and water quality // Ecological Engineering. - Vol.37, Iss.6 (June 2011), pp 963-969

15. Ziemelnieks R. Doctorate thesis „Lietus üdenu ietekme uz kopsistēmas kanalizācijas darbību" summary , LLU. Jelgava, 2011.

16. Lewis A, Rossman A. Storm Water Management Model User's Manual, Version 5.0., US EPA, Water Supply and Water Resources Division National Risk Management Research Laboratory Cincinnati, OH 45268.

17. Forschungsgesellschaft Landschaftsentwicklung Landschaftsbau e. V. fll Guideline for the Planning, Execution and Upkeep of Green-Roof Sites. Roof-Greening Guideline. January 2002.

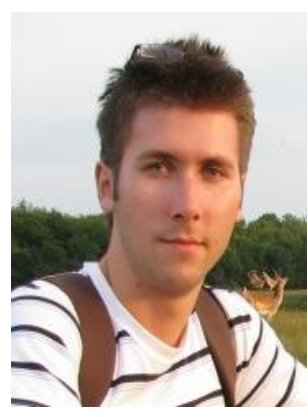

Rihards Rušenieks has gained professional bachelor degree in Transportation Systems Engineering in 2011 (Riga Technical University), master degree in Environmental Science in 2013 (Riga Technical University) and master degree in Environmental Engineering in 2013 (Vilniaus Gedimino Technikos Universitetas).

The author's work experience is data management in the International Road Carriage Co-ordination Division of State Ltd. „Road Transport Administration" and squad leadership in the Latvian National Guard. Author has had a publication in scientific journal Science - Future of Lithuania („Extensive Green Roof Development Possibilities in Latvia”) and participation by thesis in 1st World Congress of Engineers and RPI/RTU Alumni (,PLA Biopolymer Production Assessment. Case Study”).

Author is member of VGTU Alumni and BEST. Author has been awarded by Republic of Latvia National Guard commanding officer's award „For serving National Guard" (3. grade, Nr.576).

Phone: +371 26636987

e-mail: rihards.rusenieks@rtu.lv

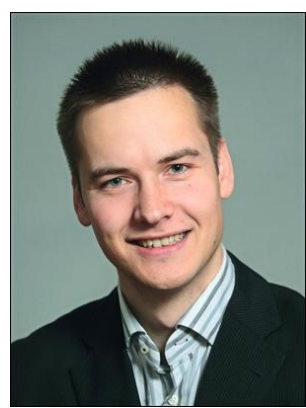

Agris Kamenders has been focusing on nearly zero energy houses, sustainable infrastructure issues, energy efficiency and cost-optimality. Agris has followed a large number of projects dealing with the implementation of energy efficiency improvement measures and the installation of energy efficiency technologies and renewable energy systems (geothermal heat pumps)

Agris has been working in a wide number of European projects, of which several under the Intelligent Europe Programme (InoFin, Build Up Skills - Latvia, MaTrID) and research framework programme (Changing behavior).

Agris has a background of thermal engineering - he graduated from the Riga Technical University (LV) and he has got a PhD. in energy efficiency from Riga Technical University with a dissertation on the renovation of existing buildings to very low energy building level, cost - optimality speaks Latvian, English and Russian.

E-mail: agris.kamenders@rtu.lv 